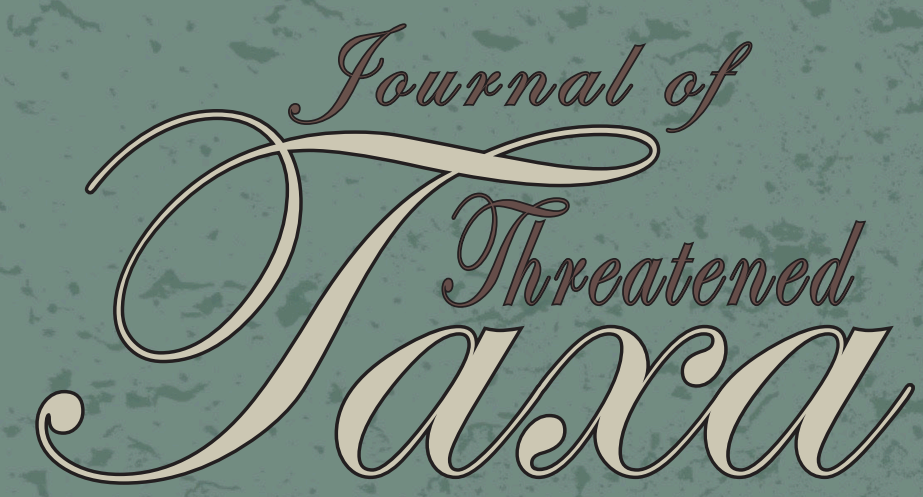

Building evidence for conservation globally
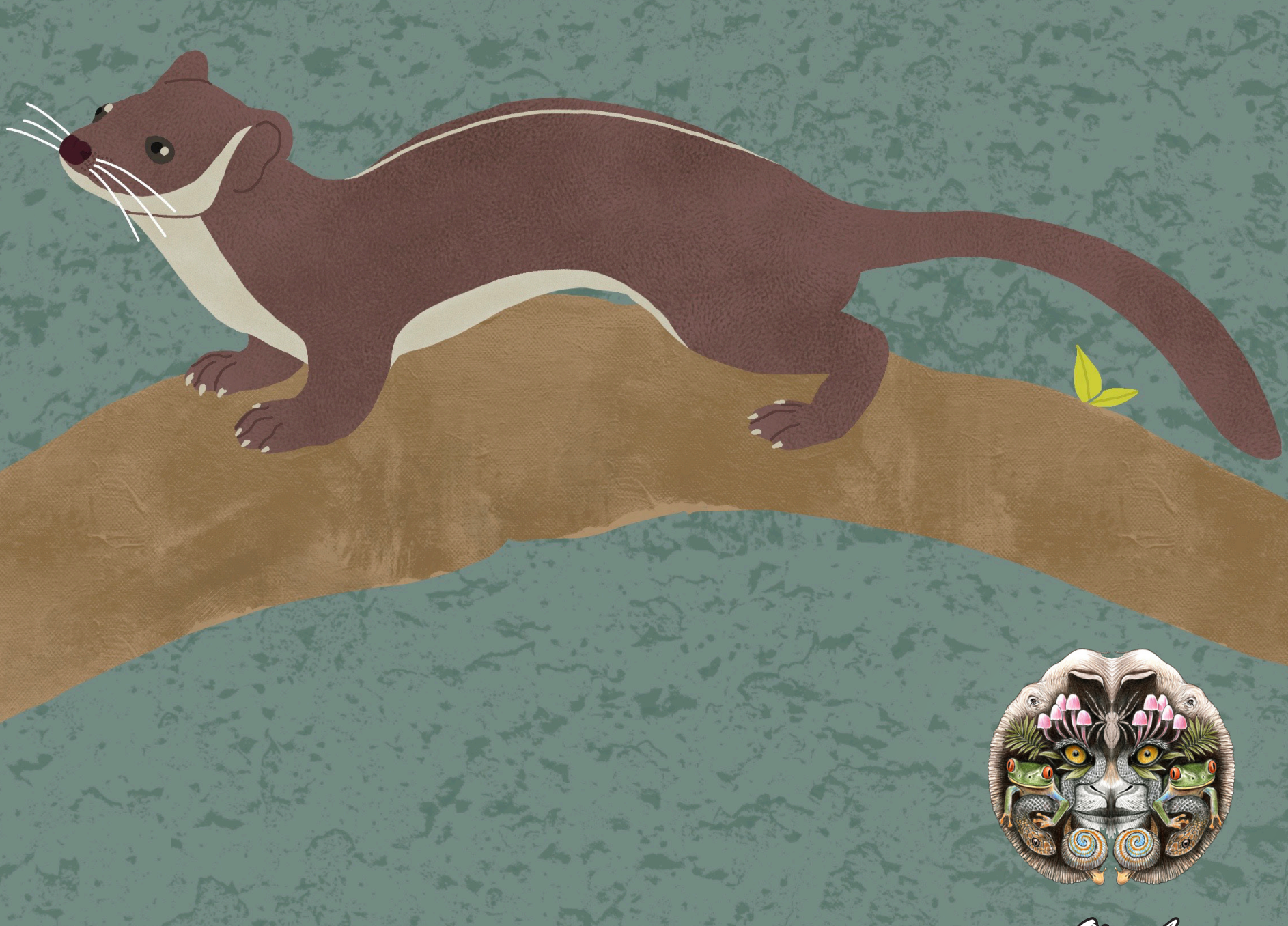

Qpecosecess

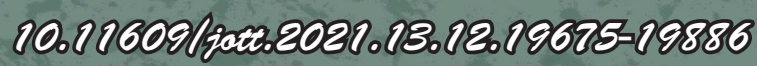
cocosurthreatecredtassararg

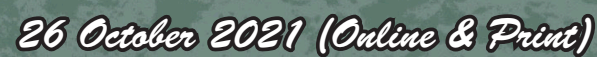

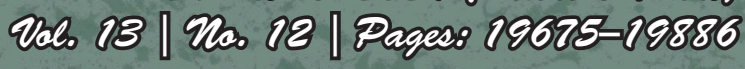




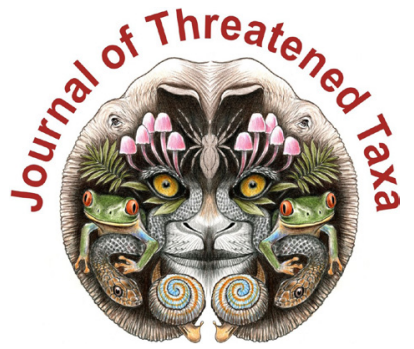

ISSN 0974-7907 (Online); ISSN $0974-7893$ (Print)

Publisher

Host

Wildlife Information Liaison Development Society

www.wild.zooreach.org

Zoo Outreach Organization www.zooreach.org

No. 12, Thiruvannamalai Nagar, Saravanampatti - Kalapatti Road, Saravanampatti, Coimbatore, Tamil Nadu 641035, India

Ph: +91 9385339863 | www.threatenedtaxa.org

Email: sanjay@threatenedtaxa.org

EDITORS

\section{Founder \& Chief Editor}

Dr. Sanjay Molur

Wildlife Information Liaison Development (WILD) Society \& Zoo Outreach Organization (ZOO)

12 Thiruvannamalai Nagar, Saravanampatti, Coimbatore, Tamil Nadu 641035, India

\section{Deputy Chief Edito}

Dr. Neelesh Dahanukar

Noida, Uttar Pradesh, India

\section{Managing Editor}

Mr. B. Ravichandran, WILD/ZOO, Coimbatore, India

\section{Associate Editors}

Dr. Mandar Paingankar, Government Science College Gadchiroli, Maharashtra 442605, India Dr. Ulrike Streicher, Wildlife Veterinarian, Eugene, Oregon, USA

Ms. Priyanka Iyer, ZOO/WILD, Coimbatore, Tamil Nadu 641035, India

Dr. B. A. Daniel, $200 /$ WIID, Coimbatore, Tamil Nadu 641035, India

\section{Editorial Board}

Dr. Russel Mittermeie

Executive Vice Chair, Conservation International, Arlington, Virginia 22202, USA

\section{Prof. Mewa Singh Ph.D., FASc, FNA, FNASc, FNAPsy}

Ramanna Fellow and Life-Long Distinguished Professor, Biopsychology Laboratory, and Institute of Excellence, University of Mysore, Mysuru, Karnataka 570006, India; Honorary Professor, Jawaharlal Nehru Centre for Advanced Scientific Research, Bangalore; and Adjunct Professor, National Institute of Advanced Studies, Bangalore

\section{Stephen D. Nash}

Scientific Illustrator, Conservation International, Dept. of Anatomical Sciences, Health Sciences Center, T-8, Room 045, Stony Brook University, Stony Brook, NY 11794-8081, USA

\section{Dr. Fred Pluthero}

Toronto, Canada

\section{Dr. Priya Davidar}

Sigur Nature Trust, Chadapatti, Mavinhalla PO, Nilgiris, Tamil Nadu 643223, India

\section{Dr. Martin Fisher}

Senior Associate Professor, Battcock Centre for Experimental Astrophysics, Cavendish

Laboratory, JJ Thomson Avenue, Cambridge CB3 OHE, UK

\section{Dr. John Fellowes}

Honorary Assistant Professor, The Kadoorie Institute, 8/F, T.T. Tsui Building, The University of Hong Kong, Pokfulam Road, Hong Kong

\section{Prof. Dr. Mirco Solé}

Universidade Estadual de Santa Cruz, Departamento de Ciências Biológicas, Vice-coordenado do Programa de Pós-Graduação em Zoologia, Rodovia Ilhéus/Itabuna, Km 16 (45662-000)

Salobrinho, Ilhéus - Bahia - Brasil

\section{Dr. Rajeev Raghavan}

Professor of Taxonomy, Kerala University of Fisheries \& Ocean Studies, Kochi, Kerala, India

\section{English Editors}

Mrs. Mira Bhojwani, Pune, India

Dr. Fred Pluthero, Toronto, Canad

Mr. P. Ilangovan, Chennai, India

Web Maintenance

Mrs. Latha G. Ravikumar, ZOO/WILD, Coimbatore, India

\section{Typesetting}

Mr. Arul Jagadish, ZOO, Coimbatore, India

Mrs. Radhika, ZOO, Coimbatore, India

Mrs. Geetha, ZOO, Coimbatore India

\section{Fundraising/Communications}

Mrs. Payal B. Molur, Coimbatore, India

Subject Editors 2018-2020

Fungi

Dr. B. Shivaraju, Bengaluru, Karnataka, India

Dr. R.K. Verma, Tropical Forest Research Institute, Jabalpur, India

Dr. Vatsavaya S. Raju, Kakatiay University, Warangal, Andhra Pradesh, India

Dr. M. Krishnappa, Jnana Sahyadri, Kuvempu University, Shimoga, Karnataka, India

Dr. K.R. Sridhar, Mangalore University, Mangalagangotri, Mangalore, Karnataka, India

Dr. Gunjan Biswas, Vidyasagar University, Midnapore, West Bengal, India

Plants

Dr. G.P. Sinha, Botanical Survey of India, Allahabad, India

Dr. N.P. Balakrishnan, Ret. Joint Director, BSI, Coimbatore, India

Dr. Shonil Bhagwat, Open University and University of Oxford, UK

Prof. D.J. Bhat, Retd. Professor, Goa University, Goa, India

Dr. Ferdinando Boero, Università del Salento, Lecce, Italy

Dr. Dale R. Calder, Royal Ontaro Museum, Toronto, Ontario, Canada

Dr. Cleofas Cervancia, Univ. of Philippines Los Baños College Laguna, Philippines

Dr. F.B. Vincent Florens, University of Mauritius, Mauritius

Dr. Merlin Franco, Curtin University, Malaysia

Dr. V. Irudayaraj, St. Xavier's College, Palayamkottai, Tamil Nadu, India

Dr. B.S. Kholia, Botanical Survey of India, Gangtok, Sikkim, India

Dr. Pankaj Kumar, Kadoorie Farm and Botanic Garden Corporation, Hong Kong S.A.R., China

Dr. V. Sampath Kumar, Botanical Survey of India, Howrah, West Bengal, India

Dr. A.J. Solomon Raju, Andhra University, Visakhapatnam, India

Dr. Vijayasankar Raman, University of Mississippi, USA

Dr. B. Ravi Prasad Rao, Sri Krishnadevaraya University, Anantpur, India

Dr. K. Ravikumar, FRLHT, Bengaluru, Karnataka, India

Dr. Aparna Watve, Pune, Maharashtra, India

Dr. Qiang Liu, Xishuangbanna Tropical Botanical Garden, Yunnan, China

Dr. Noor Azhar Mohamed Shazili, Universiti Malaysia Terengganu, Kuala Terengganu, Malaysia Dr. M.K. Vasudeva Rao, Shiv Ranjani Housing Society, Pune, Maharashtra, India

Prof. A.J. Solomon Raju, Andhra University, Visakhapatnam, India

Dr. Mandar Datar, Agharkar Research Institute, Pune, Maharashtra, India

Dr. M.K. Janarthanam, Goa University, Goa, India

Dr. K. Karthigeyan, Botanical Survey of India, India

Dr. Errol Vela, University of Montpellier, Montpellier, France

Dr. P. Lakshminarasimhan, Botanical Survey of India, Howrah, India

Dr. Larry R. Noblick, Montgomery Botanical Center, Miami, USA

Dr. K. Haridasan, Pallavur, Palakkad District, Kerala, India

Dr. Analinda Manila-Fajard, University of the Philippines Los Banos, Laguna, Philippines

Dr. P.A. Sinu, Central University of Kerala, Kasaragod, Kerala, India

Dr. Afroz Alam, Banasthali Vidyapith (accredited A grade by NAAC), Rajasthan, India

Dr. K.P. Rajesh, Zamorin's Guruvayurappan College, GA College PO, Kozhikode, Kerala, India

Dr. David E. Boufford, Harvard University Herbaria, Cambridge, MA 02138-2020, USA

Dr. Ritesh Kumar Choudhary, Agharkar Research Institute, Pune, Maharashtra, India

Dr. Navendu Page, Wildlife Institute of India, Chandrabani, Dehradun, Uttarakhand, India

Invertebrates

Dr. R.K. Avasthi, Rohtak University, Haryana, India

Dr. D.B. Bastawade, Maharashtra, India

Dr. Partha Pratim Bhattacharjee, Tripura University, Suryamaninagar, India

Dr. Kailash Chandra, Zoological Survey of India, Jabalpur, Madhya Pradesh, India

Dr. Ansie Dippenaar-Schoeman, University of Pretoria, Queenswood, South Africa

Dr. Rory Dow, National Museum of natural History Naturalis, The Netherlands

Dr. Brian Fisher, California Academy of Sciences, USA

Dr. Richard Gallon, llandudno, North Wales, LL30 1UP

Dr. Hemant V. Ghate, Modern College, Pune, India

Dr. M. Monwar Hossain, Jahangirnagar University, Dhaka, Bangladesh

Mr. Jatishwor Singh Irungbam, Biology Centre CAS, Branišovská, Czech Republic.

Dr. lan J. Kitching, Natural History Museum, Cromwell Road, UK

Dr. George Mathew, Kerala Forest Research Institute, Peechi, India

Dr. John Noyes, Natural History Museum, London, UK

For Focus, Scope, Aims, and Policies, visit https://threatenedtaxa.org/index.php/JoTT/aims_scope
For Article Submission Guidelines, visit https://threatenedtaxa.org/index.php/JoTT/about/submissions
For Policies against Scientific Misconduct, visit https://threatenedtaxa.org/index.php/JoTT/policies_various

continued on the back inside cover 


\title{
Flesh fly (Diptera: Sarcophagidae): male terminalia, diversity and expanded geographical distribution from India
}

\author{
Kanholi Sreejith ${ }^{1}$ (I), Shuvra Kanti Sinha ${ }^{2}$ (D), Santanu Mahato ${ }^{3}$ (D) \& Edamana Pushpalatha ${ }^{4}$ (D) \\ ${ }^{1,4}$ Department of Zoology, University of Calicut, Malappuram, Kerala 673635, India. \\ ${ }^{2}$ Calyptrate Research Laboratory, Department of Zoology, Sreegopal Banerjee College, Hooghly, West Bengal 712148, India. \\ ${ }^{3}$ Biopsychology Laboratory and Institution of Excellence, University of Mysore, Mysuru, Karnataka 570006, India. \\ ${ }^{1}$ sreejithkanholi@gmail.com, ${ }^{2}$ suvrosinha@gmail.com, ${ }^{3}$ santanumahato94@gmail.com, \\ ${ }^{4}$ drepushpalatha@gmail.com (corresponding author)
}

\begin{abstract}
Despite its veterinary, medical and forensic importance, the biodiversity of sarcophagid flies (Diptera: Sarcophagidae) has remained poorly investigated in India. We have performed a survey of Sarcophagidae species in connection with a study conducted on Diptera, which exposed the flesh fly diversity in and around the campus of the University of Calicut, Kerala, India. The survey was conducted using traps baited with decomposing fish and chicken liver and by the sweeping method. Eleven species were collected, including four species recorded from this state for the first time, one of which is new to the Indian mainland and the second record after Sundarbans Biosphere Reserve. Male terminalia of Sinonipponia bengalensis, Parasarcophaga choudhuryi, Boettcherisca karnyi, and Boettcherisca nathani are illustrated. This result expands the knowledge on the geographical distribution and habitat occupancy of sarcophagid species as well as their forensic relevance and provides a background for future systematic investigations.
\end{abstract}

Keywords: Abundance, Boettcherisca karnyi, Boettcherisca nathani, diversity, forensic importance, morphology, new record, Parasarcophaga, sarcophagid fly.

Abbreviations: AP-Apical plate of Paramere | LP-Lateral plate of Paramere | S-Styli of glans | T-Theca | V-Ventralia | UoCUniversity of Calicut.
Sarcophagid flies (Diptera: Sarcophagidae), commonly known as flesh flies, are abundant in all zoogeographic regions of the world with approximately 171 genera and 3,094 species (Pape et al. 2011). Out of these, 504 species in 50 genera have been described from India (Nandi 2002; Sinha \& Nandi 2002a,b). Flesh flies show a large range of feeding habits, with adult flies feeding on nectar, fruit juice, and decomposing animal matters; they carry different types of germs on their body surface, which may cause diseases in humans and other animals, and larvae of some species are parasitic on various invertebrates, breed in vertebrate and invertebrate carrion, faeces or decaying organic matter (Pape 1987, 1996; Amoudi et al. 1992; AlMisned 2000; Al-Misned et al. 2001; Graczyk et al. 2005; Pape et al. 2010; Al-Khalifa et al. 2020). This variety of feeding methods can have a direct impact on their capacity as pathogenic vectors and the larvae of some species cause myiasis in humans as well as in different animals (Dodge 1955; Zumpt 1965; Greenberg 1973, Crump \& Pounds 1985; Guimaraes \& Papavero 1999;

Citation: Sreejith, K., S.K. Sinha, S. Mahato \& E. Pushpalatha (2021). Flesh fly (Diptera: Sarcophagidae): male terminalia, diversity and expanded geographical distribution from India. Journal of Threatened Taxa 13(12): 19831-19836. https://doi.org/10.11609/jott.6568.13.12.19831-19836

Copyright: (c) Sreejith et al. 2021. Creative Commons Attribution 4.0 International License. JoTT allows unrestricted use, reproduction, and distribution of this article in any medium by providing adequate credit to the author(s) and the source of publication.

Funding: This work was carried out by the Department of Zoology, University of Calicut in collaboration with Sonamukhi College, Sonamukhi and was supported by SPG of University of Calicut, Kerala.

Competing interests: The author declares no competing interests.

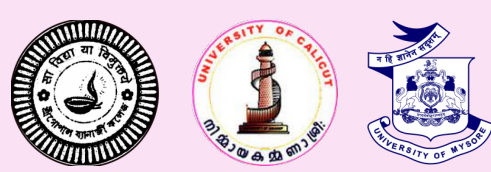

Acknowledgements: The authors are thankful to the Department of Zoology, University of Calicut for all the support given for fulfilling the work. The authors are also thankful to the Principals of Sonamukhi College, Sonamukhi, and Sreegopal Banerjee College, Hooghly, for giving the necessary permission for collaborative research with the Department of Zoology, University of Calicut, Kerala. 
Hagman et al. 2005; Stevens et al. 2006; Bermudez et al. 2010; Mello-Patiu \& Luna-Dias 2010; Kelehear et al. 2020). Whereas sarcophagid flies are associated with decomposing carcasses and human bodies (Cherix et al. 2012; Vasconcelos et al. 2014; Al-Khalifa et al. 2020), the study of larval and pupal developments found in carcasses improves their effectiveness as useful insects in forensic science investigations (Pape 1996; Wells et al. 2001; Sinha \& Mahato 2016; Ren et al. 2018; Samerjai et al. 2020).

Nandi (1990) documented nine species of flesh flies from different parts of Kerala and reported Parasarcophaga (Liosarcophaga) dux (Thomson) for the first time from Kerala. Nandi (2002) documented 20 flesh fly species in Miltogramminae (one species) and Sarcophaginae (19 species) from Kerala (Table 1). In the present faunistic survey, we aimed to contribute to the knowledge of the flesh fly diversity on the campus of the University of Calicut and the distribution of Sarcophagidae in Kerala - the most biodiversity-rich state in southern India.

\section{MATERIALS AND MEthodS}

The present survey was carried out at the University of Calicut Campus, Thenjipalam, Kerala (Figure 1).

\section{Study area}

The main campus of the University of Calicut is located in Tirurangadi Taluk of the Malappuram District, Kerala, southern India. The main campus is spread over 600 acres on the rural outskirts of Malappuram between $11.1340^{\circ} \mathrm{N}, 75.8952^{\circ} \mathrm{E}$, and the last five years have experienced a mean minimum temperature of $28.9^{\circ} \mathrm{C}$ and a mean maximum of $30.5^{\circ} \mathrm{C}$. The main habitats around the campus include gardens, botanical gardens, rubber plantations, various aquatic habitats such as ponds, paddy fields, reservoirs, orchards with mango, jackfruit, zapota, and guava, and terrestrial habitats such as primary and secondary plant successions. The Calicut University Botanical Garden (CUBG) is the largest and most diverse botanical garden of any university garden in the country, covering 45 acres and home to over 2,500 species of vascular plants. CUBG is considered one of the
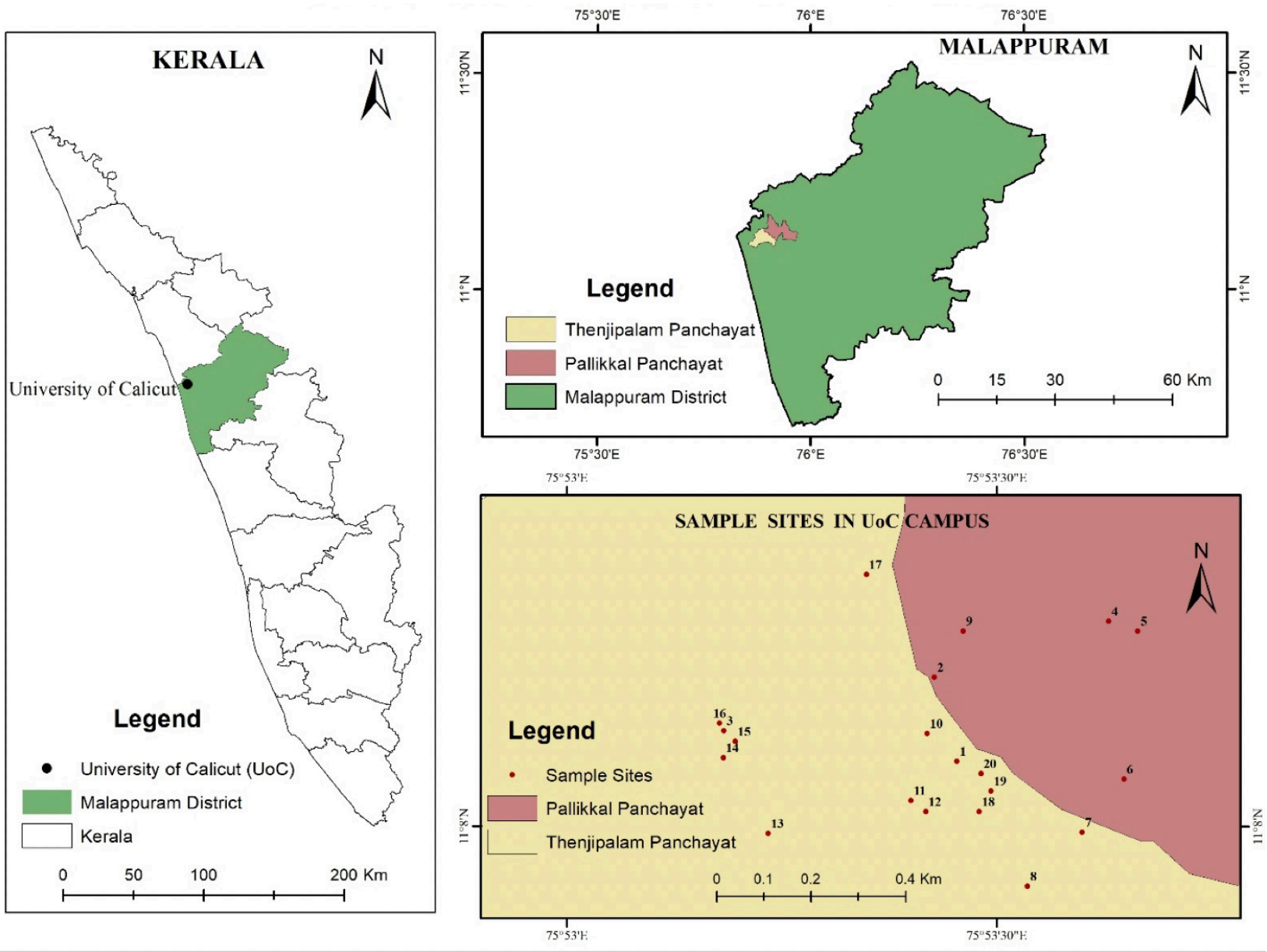

Figure 1. Sampling sites at University of Calicut (UoC). 
most important ex situ conservation centres for the rare and endangered flora of the Western Ghats, a UNESCO World Heritage site. The area receives south-west and north-east monsoons, the greater portion of the rainfall, however, is received from the south-west monsoon between June and September. The average annual rainfall of the district is $2,741 \mathrm{~mm}$ (IMD 2020).

\section{Field methods and identification}

As part of the study of dipteran diversity, a field collection programme for a faunistic survey was conducted by the team in the university campus and adjacent areas to establish documentation of flesh fly species. Collections of specimens in the university campus were done using traps baited with decomposing fish and chicken liver combined with entomological hand nets by standard sweeping. The flies were clustered around the bait, but the flies were from the Calliphoridae family and more from Muscidae. The number of flesh flies was surprisingly low. One observation was that flies were more in shady areas than in open sunshine. Flesh flies have also been found throughout the day. The specimens were identified in the laboratory using the keys, drawing illustrations of the male terminalia in Nandi (2002), and by observing chaetotaxy (arrangement of setae and bristles on the body) and the four species reported for first time from Kerala were dissected for confirmation of species identity. Since sarcophagid flies are not considerably different from each other, therefore, the characteristics of the genitalia are the only criteria for identifying them up to species level. this key was primarily focused on the characteristics of the genitalia.

Male terminalia were photographed with a Nikon Coolpix camera by keeping dissected terminalia in a cavity block under stereoscopic trinocular microscope.

\section{RESULTS}

A total of 23 individuals of flesh flies were collected from the University of Calicut campus and these were identified as comprising 11 species, of which, Nandi (2002) had previously reported seven from Kerala (Table 1). Four of the 11 species were newly recorded from the state of Kerala, i.e., Sinonipponia bengalensis Nandi, Parasarcophaga (Liosarcophaga) choudhuryi Sinha \& Nandi, Boettcherisca karnyi (Hardy), and Boettcherisca nathani Lopes. Boettcherisca karnyi (Hardy) was recorded for the first time from the Indian mainland as previously recorded from Andaman Island (Nandi 2002). The characteristic features of the four new distributional records from Kerala are quite interesting:
Table 1. Species of flesh fly recorded during this study.

\begin{tabular}{|c|c|c|c|}
\hline & Flesh fly species & Distribution & Source \\
\hline 1 & $\begin{array}{l}\text { Protomiltogramma } \\
\text { obscurior (Villeneuve) }\end{array}$ & $\begin{array}{l}\text { Coast of } \\
\text { Malabar }\end{array}$ & Nandi 2002 \\
\hline 2 & $\begin{array}{l}\text { Blaesoxipha nathani } \\
\text { Lopes }\end{array}$ & $\begin{array}{l}\text { Coast of } \\
\text { Malabar }\end{array}$ & Nandi 2002 \\
\hline 3 & $\begin{array}{l}\text { Boettcherisca peregrina } \\
\text { (R-D) }\end{array}$ & Kerala & Nandi 2002 \\
\hline 4 & $\begin{array}{l}\text { Parasarcophaga } \\
\text { ruficornis (Fabricius) }\end{array}$ & UoC, Kerala & $\begin{array}{l}\text { Nandi } 2002, \\
\text { present study }\end{array}$ \\
\hline 5 & $\begin{array}{l}\text { Parasarcophaga dux } \\
\text { (Thomson) }\end{array}$ & UoC, Kerala & $\begin{array}{l}\text { Nandi } 2002 \text {, } \\
\text { present study }\end{array}$ \\
\hline 6 & $\begin{array}{l}\text { Parasarcophaga } \\
\text { brevicornis Ho }\end{array}$ & UoC, Kerala & $\begin{array}{l}\text { Nandi 2002, } \\
\text { present study }\end{array}$ \\
\hline 7 & $\begin{array}{l}\text { Parasarcophaga } \\
\text { (Curranea) } \\
\text { scopariiformis (S-W) }\end{array}$ & Walayar Forest & Nandi 2002 \\
\hline 8 & $\begin{array}{l}\text { Parasarcophaga } \\
\text { (Pandelleisca) } \\
\text { bainbriggei (S-W) }\end{array}$ & Kurumbagram & Nandi 2002 \\
\hline 9 & $\begin{array}{l}\text { Parasarcophaga sericea } \\
\text { (Walker) }\end{array}$ & Kerala & Nandi 2002 \\
\hline 10 & $\begin{array}{l}\text { Parasarcophaga hirtipes } \\
\text { (Wiedemann) }\end{array}$ & Kerala & Nandi 2002 \\
\hline 11 & $\begin{array}{l}\text { Parasarcophaga misera } \\
\text { (Walker) }\end{array}$ & UoC, Kerala & $\begin{array}{l}\text { Nandi } 2002, \\
\text { present study }\end{array}$ \\
\hline 12 & $\begin{array}{l}\text { Parasarcophaga albiceps } \\
\text { (Meigen) }\end{array}$ & UoC, Kerala & $\begin{array}{l}\text { Nandi 2002, } \\
\text { present study }\end{array}$ \\
\hline 13 & $\begin{array}{l}\text { Robineauella walayari } \\
\text { (S-W) }\end{array}$ & $\begin{array}{l}\text { Karikal, Palghat, } \\
\text { Walayar Forest }\end{array}$ & Nandi 2002 \\
\hline 14 & $\begin{array}{l}\text { Thyrsocnema } \\
\text { (Pseudothyrsocnema) } \\
\text { longistylata Shinonaga } \\
\text { \& Lopes }\end{array}$ & $\begin{array}{l}\text { Karikal, Palghat, } \\
\text { Cinchona }\end{array}$ & Nandi 2002 \\
\hline 15 & $\begin{array}{l}\text { Thyrsocnema } \\
\text { (Pseudothyrsocnema) } \\
\text { indica Shinonaga \& } \\
\text { Lopes }\end{array}$ & $\begin{array}{l}\text { Calicut, } \\
\text { Cinchona, } \\
\text { Muttupatty, } \\
\text { Munnar }\end{array}$ & Nandi 2002 \\
\hline 16 & $\begin{array}{l}\text { Harpagophalla kempi } \\
\text { (S-W) }\end{array}$ & Trivancore & Nandi 2002 \\
\hline 17 & $\begin{array}{l}\text { Iranihindia martellata } \\
\text { (S-W) }\end{array}$ & $\begin{array}{l}\text { UoC, Kerala, } \\
\text { Willingdon } \\
\text { island }\end{array}$ & $\begin{array}{l}\text { Nandi 2002, } \\
\text { present study }\end{array}$ \\
\hline 18 & Iranihindia futilis (S-W) & $\begin{array}{l}\text { Several } \\
\text { localities }\end{array}$ & Nandi 2002 \\
\hline 19 & $\begin{array}{l}\text { Seniorwhitea reciproca } \\
\text { (Walker) }\end{array}$ & UoC, Kerala & $\begin{array}{l}\text { Nandi 2002, } \\
\text { present study }\end{array}$ \\
\hline 20 & $\begin{array}{l}\text { Leucomyia cinerea } \\
\text { (Fabricius) }\end{array}$ & Malabar Coast & Nandi 2002 \\
\hline *21 & $\begin{array}{l}\text { Sinonipponia } \\
\text { bengalensis Nandi }\end{array}$ & UoC, Kerala & present study \\
\hline *22 & $\begin{array}{l}\text { Parasarcophaga } \\
\text { (Liosarcophaga) } \\
\text { choudhuryi Sinha \& } \\
\text { Nandi }\end{array}$ & UoC, Kerala & Present study \\
\hline$* * 23$ & $\begin{array}{l}\text { Boettcherisca karnyi } \\
\text { (Hardy) }\end{array}$ & UoC, Kerala & Present study \\
\hline *24 & $\begin{array}{l}\text { Boettcherisca nathani } \\
\text { Lopes }\end{array}$ & UoC, Kerala & Present study \\
\hline
\end{tabular}

*-newly recorded from Kerala |**-newly recorded from Indian mainland. UoC-University of Calicut. 


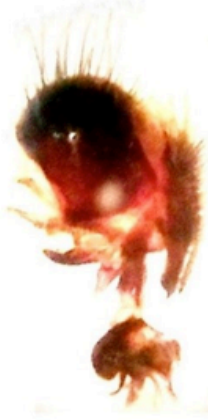

(a)

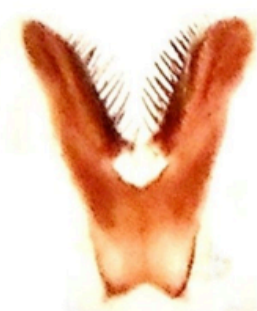

(b)
Image 1. Male genitalia of Parasarcophaga choudhuryi Sinha \& Nandi: a-inner and outer forceps, lateral view | b-fifth sternite. (C) Department of Zoology, Sonamukhi College.

\section{Parasarcophaga (Liosarcophaga) choudhuryi (Sinha \& Nandi)}

Parasarcophaga (Liosarcophaga) choudhuryi is a smaller fly with a slender body. Its ventralia is oval and wide, with a longer stylus of glans (Image 1 ). Body length 8-9 $\mathrm{mm}$. Parafrontal and parafacial black with golden pollen, the former with short scattered hairs; the latter with a row of short black hairs near the eye margin of which lower 3 are stouter. Frontal bristles 9; acrostichal bristles $0+1$, dorsocentral bristles $4+5$, mesopleural bristles $7-8$, hypopleural bristles $6-7$. Prostigmatic and propleural bristles well developed and accompanied by short hairs. $5^{\text {th }}$ sternite Y-shaped with stout spines on inner sides and long hairs terminally on arms; inner forceps slightly curved with the groove at the apex; outer forceps almost oval with few hairs terminally. Apical plate of paraphallus slightly curved backward with the anterior membranous region and elongated apical process; styli of glans slightly longer than apical plate of paraphallus and with serrations at tip; ventralia almost oval with wide trilobed, posterior lobe with the curved chitinous area.

\section{Sinonipponia bengalensis Nandi}

Sinonipponia bengalensis also is rather small in size. Its fifth sternite is characterised by the presence of a long seta. Terminalia of this species also shows peculiar features having long and pointed styli of glans, and both an apical and a lateral plate of paraphallus (Image 2). Body length 6-9 $\mathrm{mm}$. Width of frons about two-fifth that of one eye; frontal vita black, parafrontal and parafacial black with silvery pollen. Frontal bristles 10; acrostichal bristles $0+1$, dorsocentral bristles $5+4$, mesopleural bristles 6 , hypopleural bristles $8-9.5^{\text {th }}$ sternite Y-shaped with short spines laterally and one long and several

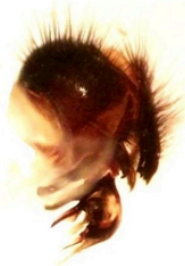

(a)

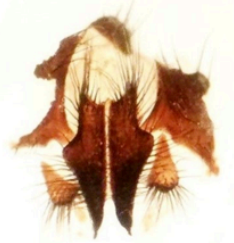

(b)

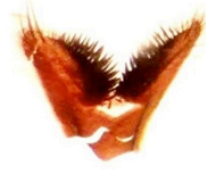

(c)

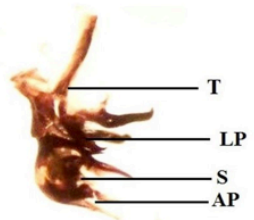

(d)

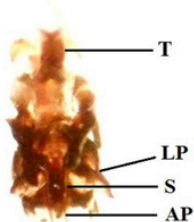

(e)
Image 2. Male genitalia of Sinonipponia bengalensis Nandi: ainner and outer forceps, lateral view | b-inner and outer forceps, posterior view | c-fifth sternite | d-penis, lateral view | e-penis, ventral view. (C) Department of Zoology, Sonamukhi College.

short hairs terminally on arms. Inner forceps almost straight, slightly curved and with a notch at the end; outer forceps dumb-bell shaped with hairs on distal end; apical plate of paraphallus pointed at end with backward projection; a lateral plate of paraphallus almost pointed, sclerotized and with basal membranous outgrowth; styli of glans long and crosses the apical part of paraphallus with anterior serrations. Ventralia black, pointed, hooklike and curved anteriorly.

\section{Boettcherisca karnyi (Hardy)}

Boettcherisca karnyi is quite similar in external appearance to Boettcherisca nathani and has minute differences in the male terminalia (Images 3). Body length 8-12 mm. Frontal bristles 11. Outer vertical bristles absent, inner vertical well developed; acrostichal bristles $0+1$, dorsocentral bristles 5+5, mesopleural bristles 5, hypopleural bristles 9. Prostigmatic and propleural bristles well developed and accompanied by short hairs. $5^{\text {th }}$ sternite Y-shaped with short window and two rows of closely set bristles laterally on arms. Apical plate of paraphallus curved pointed at the apex and with a pair of long pointed lateral processes; a lateral plate of paraphallus well developed with a pair of large two pointed unequal lateral plates of which anterior one more developed. Ventralia bilobed, well developed, spinous, and anterior margin almost rounded. 


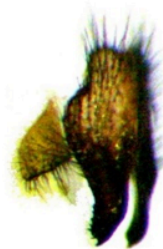

(a)

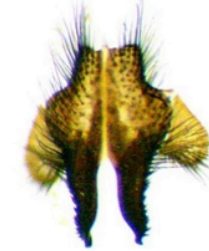

(b)

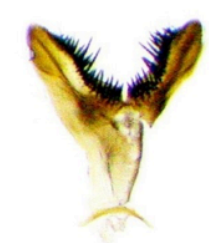

(c)

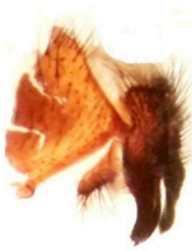

(a)

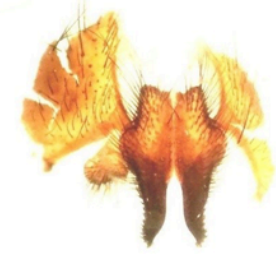

(b)

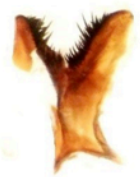

(c)

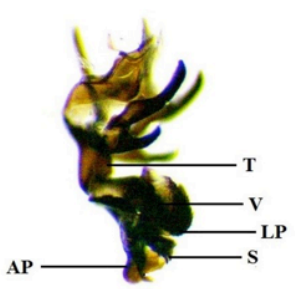

(d)

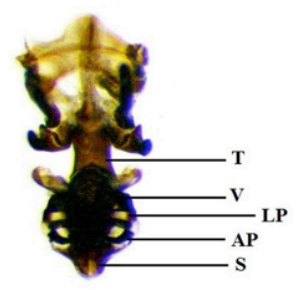

(e)
Image 3. Male genitalia of Boettcherisca karnyi (Hardy): a-inner and outer forceps, lateral view | b-inner and outer forceps, posterior view | c-fifth sternite | d-penis, lateral view | e-penis, ventral view. (c) Department of Zoology, University of Calicut.

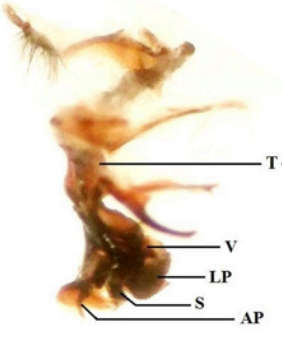

(d)

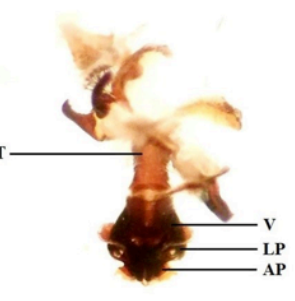

(e)
Image 4. Male genitalia of Boettcherisca nathani Lopes: a-inner and outer forceps, lateral view | b-inner and outer forceps, posterior view | c-fifth sternite | d-penis, lateral view | e-penis, ventral view. (C) Department of Zoology, Sonamukhi College.

Key to genera and species newly recorded from Kerala:

1. Ventralia large and almost rounded 2 Ventralia pointed hook-like and curved anteriorly; an apical plate of paraphallus with a backward projection; styli of glans serrated

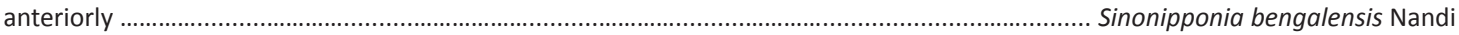

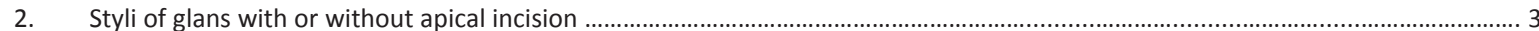
Styli of glans slightly longer than apical plate of paraphallus and with serrations at tip ................................................ Parasarcophaga (Liosarcophaga) choudhuryi (Sinha and Nandi)

3. Apical plate of paraphallus membranous; styli of glans with comb-like process anteriorly ..................... Boettcherisca nathani Lopes Apical plate of paraphallus curved pointed at the apex and with two subapical hairs; styli of glans with a median and two lateral processes. Boettcherisca karnyi (Hardy)

\section{Boettcherisca nathani Lopes}

The apical plate of paraphallus and styli of glans of Boettcherisca nathani are similar in appearance to Boettcherisca karnyi, but in Boettcherisca nathani only the ventralia part is with more digit form processes (Image 4). Body length 10-11 mm. Width of frons about three-fifth of one eye. Its width at the narrowest point of frons about more than twice that of each parafrontal; frontal bristles 12. Post gena black with numerous long brownish hairs; acrostichal bristles $0+1$, dorsocentral bristles $5+5$, mesopleural bristles 6 , hypopleural bristles 8. Inner forceps almost triangular with hairs on its broad distal end; posterior paramere terminally hook-shaped; apical plate of paraphallus membranous, curved, pointed at the apex and with a pair of long lateral processes; a lateral plate of paraphallus sclerotized with two unequal pointed processes; styli of glans with apical incision and comb-like processes anteriorly. Ventralia large with short digit form processes and its anterior margin rounded.

\section{CONCLUSIONS}

The present study on flesh fly species in the University of Calicut campus revealed a relatively high level of diversity of flesh flies showing the presence of nearly $50 \%$ of previously reported species of Kerala, in the University Campus. The species density of pulp flies is exceptionally high, but there is no evidence of the threat to these flies in the study area. Parasarcophaga (Liosarcophaga) choudhuryi Sinha \& Nandi was reported previously only from Indian Sundarbans by Sinha \& Nandi (2002) and its presence in Kerala is surprising. Boettcherisca karnyi (Hardy) was reported in India only from Andaman Islands earlier. This trend of species diversity is very astonishing and more species may be 
discovered if thorough surveys are conducted in the future. The present paper provides photographs of the male terminalia of Parasarcophaga (Liosarcophaga) choudhuryi Sinha \& Nandi, Sinonipponia bengalensis Nandi, Boettcherisca karnyi (Hardy) and Boettcherisca nathani Lopes for the first time. Moreover, the first reports of four species of flesh flies from this state along with one species newly recorded from the Indian mainland are also very attractive. Efforts should be made to study the diversity and abundance of these flies in various parts of Kerala.

\section{REFERENCES}

Al-Khalifa, M.S., A.M. Mashaly \& A.H. Al-Qahtni (2020). Insect species colonized indoor and outdoor human corpses in Riyadh, Saudi Arabia. Journal of King Saud University-Science 32(3): 1812-1817. https://doi.org/10.1016/j.jksus.2020.01.034

Al-Misned, F.A.M. (2000). Developmental time, mortality and weigh of the immature fleshfly Bercaea cruentata (Diptera: Sarcophagidae) larvae exposed to mercury. The Journal of Agricultural Science 5: 63-67. https://doi.org/10.24200/jams.vol5iss2pp63-67

Al-Misned, F.A.M., M.A. Amoudi \& S.S.M. Abou-Fannah (2001). First record of Sarcophaga (Liosarcophaga) dux Thomson, 1868 (Diptera: Sarcophagidae) from Saudi Arabia. Pakistan Journal of Zoology 33 313-315.

Amoudi, M.A., M. Leclercq \& R. Richet (1992). Rearing of a newly recorded dipterous fly Parasarcophaga (Liopygia) ruficornis (Fabricius) (Diptera: Sarcophagidae) from Saudi Arabia under laboratory conditions. Pakistan Journal of Zoology 24: 181-186.

Bermudez, C., R. Buenaventura, M. Couri, R.J. Miranda \& J.M Herrera (2010). Mixed myiasis by Philornis glaucinis (Diptera: Muscidae), Sarcodexia lambens (Diptera: Sarcophagidae) and Lucilia eximia (Diptera: Calliphoridae) in Ramphocelus dimidiatus (Aves: Thraupidae) chicks in Panama. Boletinde la SEA 47: 445-446.

Cherix, D., C. Wyss \& T. Pape (2012). Occurrences of flesh flies (Diptera: Sarcophagidae) on human cadavers in Switzerland, and their importance as forensic indicators. Forensic Science Internationa 220: 158-163. https://doi.org/10.1016/j.forsciint.2012.02.016

Crump, M.L. \& J.A. Pounds (1985). Lethal parasitism of an aposematic anuran (Atelopus varius) by Notochaeta bufonivora (Diptera: Sarcophagidae). Journal of Parasitology 71: 588-591. https://doi. org/10.2307/3281428

Dodge, H.R. (1955). Sarcophagid flies parasitic on reptiles (Diptera: Sarcophagidae). Proceedings of the Entomological Society of Washington 57: 183-187.

Graczyk, T.K., R. Knight \& L. Tamang (2005). Mechanical transmission of human protozoan parasites by insects. Clinical microbiology reviews 18: 128-132. https://doi.org/10.1128/CMR.18.1.128132.2005

Greenberg, B. (1973). Flies and Disease. Vol. II. Biology and Disease Transmission. Princeton University Press, New Jersey.

Guhathakurta, P., B.L. Sudeepkumar, P. Menon, A.K. Prasad, S.T. Sable \& S.C. Advani (2020). Observed Rainfall Variability and Changes over Kerala State. India Meteorological Department, 27 pp. https:// doi.org/10.13140/RG.2.2.25201.10087

Guimarães, J.H. \& N. Papavero (1999). Myiasis in man and animals in the Neotropical Region: Bibliographical database. São Paulo, Editora Plêiades/FAPESP, 308pp.

Hagman, M., T. Pape \& R. Schulte (2005). Flesh fly myiasis (Diptera: Sarcophagidae) in Peruvian poison frogs genus Epipedobates
(Anura, Dendrobatidae). Phyllomedusa. Journal of Herpetology 4: 69-73.

Kelehear, C., R. Ibanez, C. Rodriguez, S. Buitrago \& A.A. DurantArchibold (2020). Sarcophagid Myiasis in the Bufonid Rhinella alata in Panama. Journal of Wildlife Diseases 56(3): 667-672. https://doi. org/10.7589/2018-05-121

Mello-Patiu C.A. \& C. Luna-Dias (2010). Myiasis in the Neotropical amphibian Hypsiboas beckeri (Anura: Hylidae) by a new species of Lepidodexia (Diptera: Sarcophagidae). Journal of Parasitology 96: 685-688. https://doi.org/10.1645/GE-2423.1

Nandi, B.C. (1990). Sarcophagid Flies (Diptera: Sarcophagidae) from Tamil Nadu and Kerala, India. Records of the Zoological Survey of India 87: 151-155.

Nandi, B.C. (2002). Diptera: Sarcophagidae: Fauna of India and the adjacent countries. Zoological Survey of India 10: 1-608.

Pape, T. (1987). The Sarcophagidae (Diptera) of Fennoscandia and Denmark. Fauna Entomologica Scandinavica 19:1-203.

Pape, T. (1996). Catalogue of the Sarcophagidae of the World (Insecta: Diptera). Memoirs on Entomology, International 8: 1-558.

Pape, T., G.A. Dahlem, B.V. Brown, A. Borkent, J.M. Cumming, D.M. Wood, N.E. Woodley \& M.A. Zumbado (2010). Sarcophagidae (Flesh flies), pp. 1297-1335. Manual of Central American Diptera vol. 2.

Pape, T., V. Blagoderov \& M.B. Mostovski (2011). Order Diptera Linnaeus, 1758. In: Zhang, Z.-Q. (ed.). Animal biodiversity: An outline of higher-level classification and survey of taxonomic richness. Zootaxa 3148: 222-229. https://doi.org/10.11646/ zootaxa.3148.1.42

Ren, L., Y. Shang, W. Chen, F. Meng, J. Cai, G. Zhu \& Y. Guo (2018). A brief review of forensically important flesh flies (Diptera: Sarcophagidae). Forensic sciences research, 3: 16-26. https://doi.or g/10.1080/20961790.2018.1432099

Samerjai, C., K.L. Sukontason, N. Sontigun, K. Sukontason, T. Klongklaew, T. Chareonviriyaphap \& P. Somboon (2020). Mitochondrial DNA-Based Identification of Forensically Important Flesh Flies (Diptera: Sarcophagidae) in Thailand. Insects 11(1): 2. https://doi. org/10.3390/insects 11010002

Shannon, C.E. \& W. Weiner (1963). The Mathematical Theory of Communication. Urban University Illinois Press, 125 pp.

Sinha, S.K. \& B.C. Nandi (2002a). Parasarcophaga (Liosarcophaga) choudhuryi sp. nov. (Diptera: Sarcophagidae) from Sagar Island, Sundarbans Biosphere reserve, India. Records of the Zoological Survey of India 100: 117-121.

Sinha, S.K. \& B.C. Nandi (2002b). A new species of Lioproctia Enderlein (Diptera: Sarcophagidae) from Sundarbans Biosphere Reserve, India. Proceedings of the Zoological Society, Calcutta 55(2): 39-41

Sinha, S.K. \& S. Mahato (2016). Intra-puparial development of flesh fly Sarcophaga dux (Thomson) (Diptera, Sarcophagidae). Current Science 111: 1063-1070. https://doi.org/10.18520/cs/v111/ i6/1063-1070

Stevens, J.R., J.F. Wallman, D. Otranto, R. Wall \& T. Pape (2006). The evolution of myiasis in humans and other animals in the Old and New Worlds (part II): biological and life-history studies. Trends in Parasitology 22: 181-188. https://doi.org/10.1016/j.pt.2006.02.010

Vasconcelos, S.D., T.F. Soares \& D.L. Costa (2014). Multiple colonization of a cadaver by insects in an indoor environment: first record of Fannia trimaculata (Diptera: Fanniidae) and Peckia (Peckia) chrysostoma (Sarcophagidae) as colonizers of a human corpse. International Journal of Legal Medicine 128: 229-233. https://doi. org/10.1007/s00414-013-0936-2

Wells, J.D., T. Pape \& F.A.H. Sperling (2001). DNA-based identification and molecular systematic of forensically important Sarcophagidae (Diptera). Journal of Forensic Sciences 46: 1098-1102. https://doi. org/10.1520/JFS15105」

Zumpt, F. (1965). Myasis in man and animals in the Old World. Butterworth's, London, 267pp. 
Dr. Albert G. Orr, Griffith University, Nathan, Australia

Dr. Sameer Padhye, Katholieke Universiteit Leuven, Belgium

Dr. Nancy van der Poorten, Toronto, Canada

Dr. Kareen Schnabel, NIWA, Wellington, New Zealand

Dr. R.M. Sharma, (Retd.) Scientist, Zoological Survey of India, Pune, India

Dr. Manju Siliwal, WILD, Coimbatore, Tamil Nadu, India

Dr. G.P. Sinha, Botanical Survey of India, Allahabad, India

Dr. K.A. Subramanian, Zoological Survey of India, New Alipore, Kolkata, India

Dr. P.M. Sureshan, Zoological Survey of India, Kozhikode, Kerala, India

Dr. R. Varatharajan, Manipur University, Imphal, Manipur, India

Dr. Eduard Vives, Museu de Ciències Naturals de Barcelona, Terrassa, Spain

Dr. James Young, Hong Kong Lepidopterists' Society, Hong Kong

Dr. R. Sundararaj, Institute of Wood Science \& Technology, Bengaluru, India

Dr. M. Nithyanandan, Environmental Department, La Ala Al Kuwait Real Estate. Co. K.S.C., Kuwait

Dr. Himender Bharti, Punjabi University, Punjab, India

Mr. Purnendu Roy, London, UK

Dr. Saito Motoki, The Butterfly Society of Japan, Tokyo, Japan

Dr. Sanjay Sondhi, TITLI TRUST, Kalpavriksh, Dehradun, India

Dr. Nguyen Thi Phuong Lien, Vietnam Academy of Science and Technology, Hanoi, Vietnam

Dr. Nitin Kulkarni, Tropical Research Institute, Jabalpur, India

Dr. Robin Wen Jiang Ngiam, National Parks Board, Singapore

Dr. Lional Monod, Natural History Museum of Geneva, Genève, Switzerland.

Dr. Asheesh Shivam, Nehru Gram Bharti University, Allahabad, India

Dr. Rosana Moreira da Rocha, Universidade Federal do Paraná, Curitiba, Brasil

Dr. Kurt R. Arnold, North Dakota State University, Saxony, Germany

Dr. James M. Carpenter, American Museum of Natural History, New York, USA

Dr. David M. Claborn, Missouri State University, Springfield, USA

Dr. Kareen Schnabel, Marine Biologist, Wellington, New Zealand

Dr. Amazonas Chagas Júnior, Universidade Federal de Mato Grosso, Cuiabá, Brasil

Mr. Monsoon Jyoti Gogoi, Assam University, Silchar, Assam, India

Dr. Heo Chong Chin, Universiti Teknologi MARA (UiTM), Selangor, Malaysia

Dr. R.J. Shiel, University of Adelaide, SA 5005, Australia

Dr. Siddharth Kulkarni, The George Washington University, Washington, USA

Dr. Priyadarsanan Dharma Rajan, ATREE, Bengaluru, India

Dr. Phil Alderslade, CSIRO Marine And Atmospheric Research, Hobart, Australia

Dr. John E.N. Veron, Coral Reef Research, Townsville, Australia

Dr. Daniel Whitmore, State Museum of Natural History Stuttgart, Rosenstein, Germany.

Dr. Yu-Feng Hsu, National Taiwan Normal University, Taipei City, Taiwan

Dr. Keith V. Wolfe, Antioch, California, USA

Dr. Siddharth Kulkarni, The Hormiga Lab, The George Washington University, Washington,

D.C., USA

Dr. Tomas Ditrich, Faculty of Education, University of South Bohemia in Ceske

Budejovice, Czech Republic

Dr. Mihaly Foldvari, Natural History Museum, University of Oslo, Norway

Dr. V.P. Uniyal, Wildlife Institute of India, Dehradun, Uttarakhand 248001, India

Dr. John T.D. Caleb, Zoological Survey of India, Kolkata, West Bengal, India

Dr. Priyadarsanan Dharma Rajan, Ashoka Trust for Research in Ecology and the Environment (ATREE), Royal Enclave, Bangalore, Karnataka, India

\section{Fishes}

Dr. Neelesh Dahanukar, IISER, Pune, Maharashtra, India

Dr. Topiltzin Contreras MacBeath, Universidad Autónoma del estado de Morelos, México

Dr. Heok Hee Ng, National University of Singapore, Science Drive, Singapore

Dr. Rajeev Raghavan, St. Albert's College, Kochi, Kerala, India

Dr. Robert D. Sluka, Chiltern Gateway Project, A Rocha UK, Southall, Middlesex, UK

Dr. E. Vivekanandan, Central Marine Fisheries Research Institute, Chennai, India

Dr. Davor Zanella, University of Zagreb, Zagreb, Croatia

Dr. A. Biju Kumar, University of Kerala, Thiruvananthapuram, Kerala, India

Dr. Akhilesh K.V., ICAR-Central Marine Fisheries Research Institute, Mumbai Research

Centre, Mumbai, Maharashtra, India

Dr. J.A. Johnson, Wildlife Institute of India, Dehradun, Uttarakhand, India

\section{Amphibians}

Dr. Sushil K. Dutta, Indian Institute of Science, Bengaluru, Karnataka, India

Dr. Annemarie Ohler, Muséum national d'Histoire naturelle, Paris, France

\section{Reptiles}

Dr. Gernot Vogel, Heidelberg, Germany

Dr. Raju Vyas, Vadodara, Gujarat, India

Dr. Pritpal S. Soorae, Environment Agency, Abu Dubai, UAE.

Prof. Dr. Wayne J. Fuller, Near East University, Mersin, Turkey

Prof. Chandrashekher U. Rivonker, Goa University, Taleigao Plateau, Goa. India

Dr. S.R. Ganesh, Chennai Snake Park, Chennai, Tamil Nadu, India

Dr. Himansu Sekhar Das, Terrestrial \& Marine Biodiversity, Abu Dhabi, UAE
Birds

Dr. Hem Sagar Baral, Charles Sturt University, NSW Australia

Dr. Chris Bowden, Royal Society for the Protection of Birds, Sandy, UK

Dr. Priya Davidar, Pondicherry University, Kalapet, Puducherry, India

Dr. J.W. Duckworth, IUCN SSC, Bath, UK

Dr. Rajah Jayapal, SACON, Coimbatore, Tamil Nadu, India

Dr. Rajiv S. Kalsi, M.L.N. College, Yamuna Nagar, Haryana, India

Dr. V. Santharam, Rishi Valley Education Centre, Chittoor Dt., Andhra Pradesh, India

Dr. S. Balachandran, Bombay Natural History Society, Mumbai, India

Mr. J. Praveen, Bengaluru, India

Dr. C. Srinivasulu, Osmania University, Hyderabad, India

Dr. K.S. Gopi Sundar, International Crane Foundation, Baraboo, USA

Dr. Gombobaatar Sundev, Professor of Ornithology, Ulaanbaatar, Mongolia

Prof. Reuven Yosef, International Birding \& Research Centre, Eilat, Israel

Dr. Taej Mundkur, Wetlands International, Wageningen, The Netherlands

Dr. Carol Inskipp, Bishop Auckland Co., Durham, UK

Dr. Tim Inskipp, Bishop Auckland Co, Durham, UK

Dr. V. Gokula, National College, Tiruchirappalli, Tamil Nadu, India

Dr. Arkady Lelej, Russian Academy of Sciences, Vladivostok, Russia

Dr. Simon Dowell, Science Director, Chester Zoo, UK

Dr. Mário Gabriel Santiago dos Santos, Universidade de Trás-os-Montes e Alto Douro,

Quinta de Prados, Vila Real, Portugal

Dr. Grant Connette, Smithsonian Institution, Royal, VA, USA

Dr. M. Zafar-ul Islam, Prince Saud Al Faisal Wildlife Research Center, Taif, Saudi Arabia

Mammals

Dr. Giovanni Amori, CNR - Institute of Ecosystem Studies, Rome, Italy

Dr. Anwaruddin Chowdhury, Guwahati, India

Dr. David Mallon, Zoological Society of London, UK

Dr. Shomita Mukherjee, SACON, Coimbatore, Tamil Nadu, India

Dr. Angie Appel, Wild Cat Network, Germany

Dr. P.O. Nameer, Kerala Agricultural University, Thrissur, Kerala, India

Dr. Ian Redmond, UNEP Convention on Migratory Species, Lansdown, UK

Dr. Heidi S. Riddle, Riddle's Elephant and Wildlife Sanctuary, Arkansas, USA

Dr. Karin Schwartz, George Mason University, Fairfax, Virginia.

Dr. Lala A.K. Singh, Bhubaneswar, Orissa, India

Dr. Mewa Singh, Mysore University, Mysore, India

Dr. Paul Racey, University of Exeter, Devon, UK

Dr. Honnavalli N. Kumara, SACON, Anaikatty P.O., Coimbatore, Tamil Nadu, India

Dr. Nishith Dharaiya, HNG University, Patan, Gujarat, India

Dr. Spartaco Gippoliti, Socio Onorario Società Italiana per la Storia della Fauna "Giuseppe

Altobello", Rome, Italy

Dr. Justus Joshua, Green Future Foundation, Tiruchirapalli, Tamil Nadu, India

Dr. H. Raghuram, The American College, Madurai, Tamil Nadu, India

Dr. Paul Bates, Harison Institute, Kent, UK

Dr. Jim Sanderson, Small Wild Cat Conservation Foundation, Hartford, USA

Dr. Dan Challender, University of Kent, Canterbury, UK

Dr. David Mallon, Manchester Metropolitan University, Derbyshire, UK

Dr. Brian L. Cypher, California State University-Stanislaus, Bakersfield, CA

Dr. S.S. Talmale, Zoological Survey of India, Pune, Maharashtra, India

Prof. Karan Bahadur Shah, Budhanilakantha Municipality, Kathmandu, Nepal

Dr. Susan Cheyne, Borneo Nature Foundation International, Palangkaraja, Indonesia

Dr. Hemanta Kafley, Wildlife Sciences, Tarleton State University, Texas, USA

\section{Other Disciplines}

Dr. Aniruddha Belsare, Columbia MO 65203, USA (Veterinary)

Dr. Mandar S. Paingankar, University of Pune, Pune, Maharashtra, India (Molecular)

Dr. Jack Tordoff, Critical Ecosystem Partnership Fund, Arlington, USA (Communities)

Dr. Ulrike Streicher, University of Oregon, Eugene, USA (Veterinary)

Dr. Hari Balasubramanian, EcoAdvisors, Nova Scotia, Canada (Communities)

Dr. Rayanna Hellem Santos Bezerra, Universidade Federal de Sergipe, São Cristóvão, Brazil

Dr. Jamie R. Wood, Landcare Research, Canterbury, New Zealand

Dr. Wendy Collinson-Jonker, Endangered Wildlife Trust, Gauteng, South Africa

Dr. Rajeshkumar G. Jani, Anand Agricultural University, Anand, Gujarat, India

Dr. O.N. Tiwari, Senior Scientist, ICAR-Indian Agricultural Research Institute (IARI), New

Delhi, India

Dr. L.D. Singla, Guru Angad Dev Veterinary and Animal Sciences University, Ludhiana, India

Dr. Rupika S. Rajakaruna, University of Peradeniya, Peradeniya, Sri Lanka

Dr. Bahar Baviskar, Wild-CER, Nagpur, Maharashtra 440013, India

Reviewers 2018-2020

Due to pausity of space, the list of reviewers for 2018-2020 is available online.
The opinions expressed by the authors do not reflect the views of the Journal of Threatened Taxa, Wildlife Information Liaison Development Society, Zoo Outreach Organization, or any of the partners. The journal, the publisher, the host, and the partners are not responsible for the accuracy of the political boundaries shown in the maps by the authors.

\footnotetext{
Print copies of the Journal are available at cost. Write to:

The Managing Editor, JoTT,

c/o Wildlife Information Liaison Development Society,

No. 12, Thiruvannamalai Nagar, Saravanampatti - Kalapatti Road,

Saravanampatti, Coimbatore, Tamil Nadu 641035, India

ravi@threatenedtaxa.org
} 


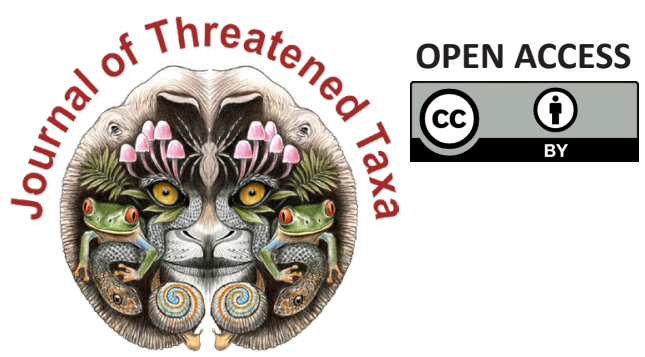

www.threatenedtaxa.org

The Journal of Threatened Taxa (JoTT) is dedicated to building evidence for conservation globally by publishing peer-reviewed articles online every month at a reasonably rapid rate at www.threatenedtaxa.org. All articles published in JoTT are registered under Creative Commons Attribution 4.0 International License unless otherwise mentioned. JoTT allows allows unrestricted use, reproduction, and distribution of articles in any medium by providing adequate credit to the author(s) and the source of publication.

\section{ISSN $0974-7907$ (Online) | ISSN $0974-7893$ (Print)}

\section{October 2021 | Vol. 13 | No. 12 | Pages: 19675-19886 \\ Date of Publication: 26 October 2021 (Online \& Print) DOI: 10.11609/jott.2021.13.12.19675-19886}

Articles

Roosting habits and habitats of the Indian Flying Fox Pteropus medius Temminck, 1825 in the northern districts of Tamil Nadu, India

- M. Pandian \& S. Suresh, Pp. 19675-19688

Diversity and distribution of avifauna at Warathenna-Hakkinda Environmental Protection Area in Kandy, Sri Lanka

- Dinelka Thilakarathne, Tithira Lakkana, Gayan Hirimuthugoda, Chaminda Wijesundara \& Shalika Kumburegama, Pp. 19689-19701

Grass species composition in tropical forest of southern India

- M. Ashokkumar, S. Swaminathan \& R. Nagarajan, Pp. 19702-19713

\section{Communications}

Habitat use and conservation threats to Wild Water Buffalo Bubalus arnee (Mammalia: Artiodactyla: Bovidae) in Koshi Tappu Wildlife Reserve, Nepal

- Reeta Khulal, Bijaya Neupane, Bijaya Dhami, Siddhartha Regmi, Ganesh Prasad Tiwari \& Manita Parajuli, Pp. 19714-19724

Get my head around owls: people perception and knowledge about owls of Andaman Islands

- Shanmugavel Sureshmarimuthu, Santhanakrishnan Babu, Nagaraj Rajeshkumar \& Honnavalli Nagaraj Kumara, Pp. 19725-19732

Abundance and diversity of threatened birds in Nangal Wetland, Punjab, India - Rajwinder Kaur \& Onkar Singh Brraich, Pp. 19733-19742

Evaluation of fish diversity and abundance in the Kabul River with comparisons between reaches above and below Kabul City, Afghanistan

- Ugyen Kelzang, Ahmad Farid Habibi \& Ryan J. Thoni, Pp. 19743-19752

New record of Myrmarachne melanocephala MacLeay, 1839 (Araneae: Salticidae) from Jharkhand, India and biogeographical implications of the co-occurrence of its ant model Tetraponera rufonigra Jerdon, 1851

- Rahul Kumar, Mirtunjay Sharma \& Ajay Kumar Sharma, Pp. 19753-19761

Diversity of spiders (Arachnida: Araneae) and the impact of pruning in Indian sandalwood plantations from Karnataka, India

-S. Padma 1 \& R. Sundararaj, Pp. 19762-19772

New records of cheilostome Bryozoa from the eastern coast of India encrusting on the exoskeleton of live horseshoe crabs of Indian Sundarbans

- Swati Das, Maria Susan Sanjay, Basudev Tripathy, C. Venkatraman \& K.A. Subramanian, Pp. 19773-19780

On the pteridophytes of Bherjan-Borajan-Padumoni Wildlife Sanctuary, Assam, India - Pranjal Borah \& Jayanta Barukial, Pp. 19781-19790

Population status of Heritiera fomes Buch.-Ham., a threatened species from Mahanadi Mangrove Wetland, India

- Sudam Charan Sahu, Manas Ranjan Mohanta \& N.H. Ravindranath, Pp. 19791-19798

Additions to the lichenized and lichenicolous fungi of Jammu \& Kashmir from Kishtwar High Altitude National Park

- Vishal Kumar, Yash Pal Sharma, Siljo Joseph, Roshinikumar Ngangom \& Sanjeeva Nayaka, Pp. 19799-19807

\section{Short Communications}

Is release of rehabilitated wildlife with embedded lead ammunition advisable? Plumbism in a Jaguar Panthera Onca (Mammalia: Carnivora: Felidae), survivor of gunshot wounds - Eduardo A. Díaz, Carolina Sáenz, E. Santiago Jiménez, David A. Egas \& Kelly Swing, Pp. 19808-19812

New record of the Sewing Needle Zipper Loach Paracanthocobitis linypha Singer \& Page, 2015 (Teleostei: Cypriniformes: Nemacheilidae) from the Chindwin drainage of Manipur, India

- Yumnam Rameshori, Yengkhom Chinglemba \& Waikhom Vishwanath, Pp. 19813-19817

Field identification characters to diagnose Microhyla mukhlesuri from closely related M. mymensinghensis (Amphibia: Microhylidae) and range extension of $M$. mukhlesuri up to West Bengal State, India

- Suman Pratihar \& Kaushik Deuti, Pp. 19818-19823
First report of Scipinia horrida (Stål) (Heteroptera: Reduviidae) from Assam, with comments on related genus Irantha Stål

- Anjana Singha Naorem, Santana Saikia, Anandita Buragohain, Rubina Azmeera Begum, Swapnil S. Boyane \& Hemant V. Ghate, Pp. 19824-19830

Flesh fly (Diptera: Sarcophagidae): male terminalia, diversity and expanded geographical distribution from India

- Kanholi Sreejith, Shuvra Kanti Sinha, Santanu Mahato \& Edamana Pushpalatha, Pp. 1983119836

Checklist of moths (Heterocera) of Tadong, Sikkim, India

- Prayash Chettri, Yuki Matsui, Hideshi Naka \& Archana Tiwari, Pp. 19837-19848

New distribution records of Begonia L., B. murina Craib and B. poilanei Kiew (Begoniaceae: Cucurbitales) for Laos

- Phongphayboun Phonepaseuth, Phetlasy Souladeth, Soulivanh Lanorsavanh, Shuichiro Tagane, Thyraphon Vongthavone \& Keooudone Souvannakhoummane Pp. 19849-19854

Notes

A recent sighting of the Stripe-backed Weasel Mustela strigidorsa (Mammalia: Carnivora: Mustelidae) in Hkakabo Razi Landscape, Myanmar

- Sai Sein Lin Oo, Tun Tun, Kyaw Myo Naing \& Paul Jeremy James Bates, Pp. 19855-19859

Are the uplifted reef beds in North Andaman letting nesting Olive Ridley Sea Turtle Lepidochelys olivacea stranded?

- Nehru Prabakaran, Anoop Raj Singh \& Vedagiri Thirumurugan, Pp. 19860-19863

First record of the orb-weaving spider Araneus tubabdominus Zhu \& Zhang, 1993 (Araneae: Araneidae) from India

- Souvik Sen, John T.D. Caleb \& Shelley Acharya, Pp. 19864-19866

The genus Catapiestus Perty, 1831 (Coleoptera: Tenebrionidae: Cnodalonini) from Arunachal Pradesh with one new record to India

- V.D. Hegde \& Sarita Yadav, Pp. 19867-19869

Rediscovery and extended distribution of Indigofera santapaui Sanjappa (Leguminosae: Papilionoideae) from the states of Maharashtra and Gujarat, India

- Kumar Vinod Chhotupuri Gosavi, Sanjay Gajanan Auti, Sharad Suresh Kambale \& Munivenkatappa Sanjappa, Pp. 19870-19873

Additional distribution records of Ceropegia anjanerica, an endemic and 'Endangered' lantern flower of the northern Western Ghats, India

- Samir Shrikant Maity, Ajay Natha Gangurde, Sharad Suresh Kambale, Avinash Ramchandra Gholave, Avinash Asraji Adsul, Ganesh Babaso Pawar \& Kumar Vinod Chhotupuri Gosavi, Pp. 19874-19877

Notes on the extended distribution of Impatiens megamalayana, a recently described balsam in Western Ghats, India

- Anoop P. Balan \& A.J. Robi, Pp. 19878-19883

Book Review

A look over on the scented tree of India (Santalum album - S. Suresh Ramanan \& A. Arunachalam, Pp. 19884-19886
Publisher \& Host
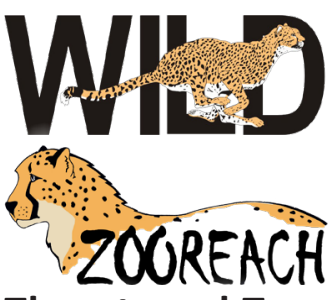

Threatened Taxa 